Check for updates

Cite this: RSC Adv., 2019, 9, 23894

\title{
Functionalized gold nanostructures: promising gene delivery vehicles in cancer treatment
}

\author{
Sanjay Kumar, Anchita Diwan, Parinita Singh, Shikha Gulati, (D) * Devanshu Choudhary, \\ Ayush Mongia, Shefali Shukla and Akanksha Gupta
}

Surface-modified gold nanoparticles are recognized as promising gene delivery vehicles in the treatment of cancer owing to their excellent biocompatibility with biomolecules (like DNA or RNA) and their unique optical and structural properties. In this context, this review article focuses on the diverse transfection abilities of the gene to the targeted cell on the basis of different shapes and sizes of gold nanoparticles in order to promote its effective expression for cancer treatment. In addition, recent trends in gold nanoparticle mediated gene silencing, gene delivery, detection and combinatory therapies are highlighted considering their cytotoxic effects on healthy human cells.

Received 14th May 2019

Accepted 19th July 2019

DOI: $10.1039 / c 9 r a 03608 c$

rsc.li/rsc-advances

chemical stability, biocompatibility, effective targeting, stimulus

\section{Introduction}

Cancer, with high incidence and deregulated cell growth, has caused death all over the world. Conventionally, cancer treatment relied mainly upon tumour resection along with chemotherapy, where there is non-specific accumulation of drugs and/or radiotherapy resulting in various side effects. A large number of cancer cells have become drug resistant towards these therapies mostly due to the molecular mechanism. These drawbacks of the traditional approach towards treatment of cancer can be overcome by combining gene therapy with other related therapies such as chemotherapy, photothermal therapy, photodynamic therapy, etc. ${ }^{1-4}$ Gene delivery vectors reported in recent years, include polymerbased, lipid-based, and inorganic nanoparticle-based systems. ${ }^{.-9}$ Ideal non-viral gene vectors offer numerous advantages, such as

Department of Chemistry, Sri Venkateswara College, University of Delhi, Delhi-110021, India.E-mail: shikha2gulati@gmail.com responsiveness and feasibility for combined treatments. ${ }^{2-4}$ Due to irregular signalling pathways and genetic alterations, the concept of novel molecularly targeted therapeutic strategies such as genesilencing or knockdown therapies have been introduced. ${ }^{10-14}$ RNA interference (RNAi), one of the significant gene therapy approaches followed by tumour resection has fascinated researchers in cancer treatment, ${ }^{15}$ where microRNA (miRNA) and plasmid DNA (pDNAs) are frequently utilized because of their higher stability and specificity than those of small interfering RNA (siRNA). ${ }^{16,17}$ Surfacemodified gold nanomaterials are acknowledged as favourable gene delivery vehicles, ${ }^{18-21}$ in consequence of their small size, general non-toxicity, ease of functionalization and high surface to volume ratio, localized surface plasmon resonance (LSPR) of gold nanoparticles resulting in improved consideration from non-viral siRNA gene delivery. ${ }^{11,22,23}$ Additionally, these nanoparticles can also be used for imaging of tumours by computed tomography, a leading radiologic technology in the field of biomedical imaging. ${ }^{24}$

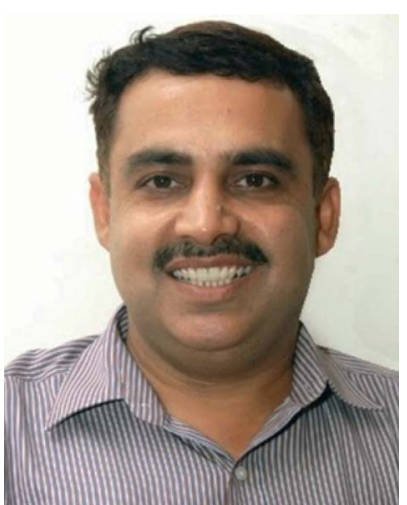

Dr Sanjay Kumar has been working as an Associate Professor in Department of Chemistry, Sri Venkateswara College, University of Delhi since 2000. He did his $\mathrm{PhD}$ in the field of molecular spectroscopy from University of Delhi in 1998. He has also worked as a post-doctoral fellow at IGIB, New Delhi in the field of molecular immunology. Currently he is focusing in the field of nanotechnology and

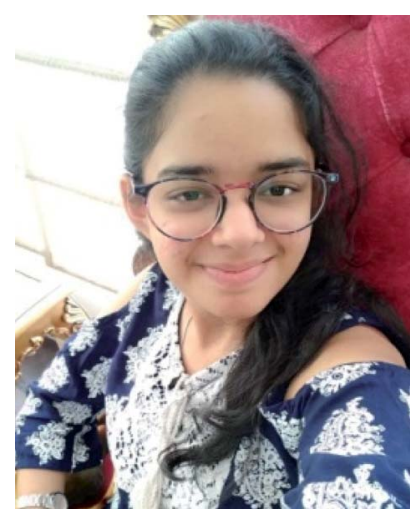

Anchita Diwan was born in Delhi, India, in 2000. Currently she is pursuing BSc(Honors) Chemistry from Sri Venkateswara College, University of Delhi. Her main research interests are in organic chemistry, nanotechnology, biotechnology and pharmacy. Also she is interested in research field to find cure of diseases like AIDS and cancer.

cancer research. 
In continuation of our research work in the field of nanomaterials and cancer treatment, ${ }^{25-30}$ the current review focuses on advanced accomplishments of gene therapy in conjugation with gold nanoparticles that stand out as potential candidates for anti-oncological approaches. In addition, detailed mechanisms like gene silencing, gene delivery along with detection and imaging are discussed both in vitro and in vivo.

\section{Evaluation of gold nanoparticles in gene silencing}

The commendable contributions of AuNPs in gene silencing have enhanced the treatment of cancer drastically. Various recent reports have shown effectiveness utilizing this approach as shown in Table 1 . Table 1 shows the cellular recognition and entry of the nanoparticles, of different size and shape at tumor sites for knockdown. RNA interference (RNAi), one of the gene therapy approaches offered has attracted interest in cancer treatment due to its high specificity and efficiency and the relatively minor upshots. ${ }^{31,32}$ Over the decade, a novel strategy for detection and gene knockdown has been introduced using RNA interference. ${ }^{33,34}$ Telomerase which is highly expressed in many types of cancer cells whose activity inhibition using human telomerase reverse transcriptase (hTERT) has been investigated in oncology. ${ }^{35}$ However, there are challenges that hinder the efficient delivery of hTERTsiRNA at the tissue level as well as the intracellular levels (Fig. 1). ${ }^{36-38}$

Under the influence of LED radiation, the Chromium-doped zinc gallate nanoparticles $\mathrm{ZnGa}_{2}-x \mathrm{O}_{4}: \mathrm{Cr}_{x}$ (ZGOC) nanofiber emission could be absorbed selectively by gold nanorods (AuNRs), which induces a mild photothermal effect that in turn triggers the liberation of the particles from ZGOC nanofibers, localized drug delivery systems (LDDSs), and enhances the

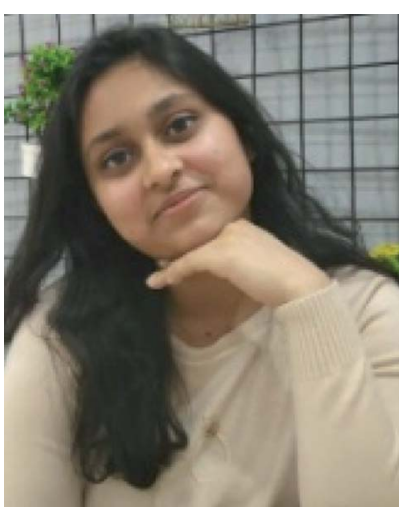

Parinita Singh was born in Delhi, India, in 2000. She completed her senior secondary education from Holy Child Auxilium School in 2018. She is currently pursuing her bachelor's degree in chemistry from Sri Venkateswara College, Delhi University. Her research interest includes synthesis and application of nanomaterials and nanosciences.

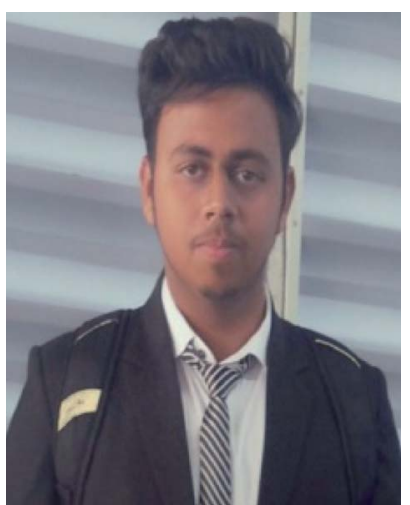

Devanshu Choudhary was born in Haryana, India, in 1999. His extreme curiosity about numerological disorders and drug synthesis with it's mechanism led him to pursue chemistry as his field of studies. Currently he is pursuing bachelors in chemistry from Sri Venkateswara College - University of Delhi. His research interests include nanomaterials, drug targeting mechanism and drug synthesis, for neurological and many other biological disorders. He believes with consistent work and a new practice, a new change can be brought in the field of modern therapeutics. Neurological disorders and cancer are one of the most preferred disorders he is passionate to study and research upon.

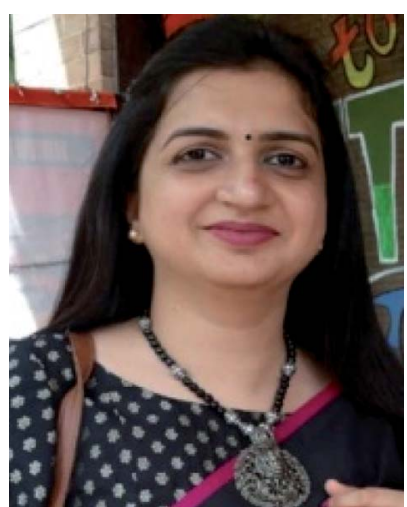

Dr Shikha Gulati is working as an Assistant Professor of Chemistry in Sri Venkateswara College, Univeristy of Delhi. She is native of Delhi, India with $\mathrm{MSc}$ and $\mathrm{BSc}(\mathrm{H})$ Chemistry from the University of Delhi, India. She joined Green Chemistry Network Centre Department of Chemistry, University of Delhi in 2009 as a Doctoral student. She has authored several research papers in International Journals, and written numerous books as well as chapters in diverse books which attest to her hard work, research aptitude, and good writing skills. Her research interests include Nanomaterials, Green Chemistry, Analytical Chemistry and fabrication of anti-cancer agents.

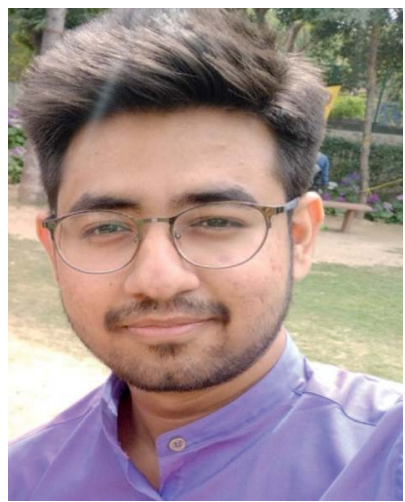

Ayush Mongia was born in Delhi, India, in 1999. His extreme curiosity about biological disorders and drug synthesis and delivery led him to pursue chemistry as his field of studies. Currently he is pursuing Bachelors in Chemistry from Sri Venkateswara College - University of Delhi. His research interests include nanomaterials, drug synthesis and delivery, cancer and many other biological disorders. He believes with consistent work and a powerful imagination, a new change can be brought in the field of modern therapeutics. Aids and cancer are one of the most preferred disorders he is passionate to study and research upon. 
cellular uptake and the therapeutic effect. The new therapeutic platform, with LED-amplified gene silencing has therefore inspired another potential system to enhance gene therapy in cancer treatment. The successful RNAi lies in the effective release of siRNA from the endosomes, which can destroy the target mRNA in the cytoplasm and inhibit the expression of the target protein. ${ }^{39}$ Post conjugation of mRNA, siRNA instigates degradation of mRNA, hence significantly reducing protein expression by targeting the gene. ${ }^{\mathbf{3 4 , 4 0}}$ In a study, to therapeutically target eukaryotic elongation factor 2 kinase (eEF-2K), which has been identified as an important oncogenic pathways for promoting breast cancer. Kezban et al. synthesized a highly monodisperse and stable nano-formulation using polyethylenimine-modified gold nanoparticles (AUNP-PEI) and conjugated them with eEF-2K siRNA. Hence, down regulation of triple negative breast cancer cells (TNBC) using AuNP-PEI/eEF2K siRNA was observed in vitro. ${ }^{33}$

To make sure the better detection and therapeutic effect, antimiR-21 strands are fully modified by $2^{\prime}$-O-methyl to increase binding affinity with tumor gene and improve stability and resistance to exonucleases to prolonged inhibition of miRNAs. ${ }^{\mathbf{4 1}}$ Recent studies have shown that Taxol, a chemotherapeutic drug initially induces apoptosis of cancer cells, but on prolonged treatment, the cancer cells become immune to this drug and to other drugs as well. ${ }^{\mathbf{4 2 , 4 3}}$ This resistance of cancer cells towards these chemotherapeutic drugs is called multidrug resistance (MDR) ${ }^{44}$ Various studies have reported that P-glycoprotein (PgP) is overexpressed in MDR cell lines. ${ }^{45}$ The reduction in the expression of P-gp could be done using hyperthermia. ${ }^{46}$ Also, microRNA-21 (miR-21) a type of miRNA could be downregulated resulting in inhibiting tumor progression and invasion.47,48 miRNA, is advantageous in promoting cell invasion by regulating various genes, including programmed cell death 4 (PDCD4) gene, tissue inhibitor of metallopeptidase inhibitor 3 (TIMP3), phosphatase and tensin homolog (PTEN) gene in a variety of tumors, such as lung cancer, glioblastoma, and breast cancer. $^{49}$ AuNPs are functionalized with miRNA-21 inhibitors that are hybridized with fluorophore-labeled DNA molecules named "flares", miRNA-21 inhibitors are 2'-O-methyl modified antisense oligonucleotide that are complementary to the mature miRNA-21 to suppress its function, resulting in cells growth inhibition and apoptotic cells death, as shown in Fig. 2. ${ }^{50}$ Cancer stem cell (CSC) with the mark of CD44 plays an important role in gastric cancer (GC). The transfection of rMETase carried by HA-G5 PAMAM-Au visibly inhibited the escalation and tumor sphere formation of GC cells through promoting METase activity. Elevated level of methionine (MET) promotes self-growth of cancer cells. Suppression of CD44(+) GC resulted because of downregulation of METase activity, which lead to increase of Cyc $\mathrm{C}$ and ROS levels. For instance, the p53 and HSV-TK suppressed the proliferation and promoted apoptosis of cancer cells. ${ }^{51,52}$ No effect on healthy cells was observed due to the low concentration of MET. ${ }^{53}$ Owing to the excellent structural properties (PAMAM) is found to be suitable in conjugation with metallic nanoparticles. ${ }^{54}$ Improvement in efficacy of gene transfecting COS-7 cells and shape maintenance of dendrimers was caused through G5-PAMAM encapsulated gold nanoparticles. ${ }^{55}$ Additionally, hyaluronic acid (HA) was conjugated onto PAMAM for targeting CD44 + gastric cancer stem cells specifically. ${ }^{56}$

Another instance of this approach is demonstrated by the use of folic acid (FA) due to its replication control, cell proliferation, synthesis of proteins and biocompatibility. ${ }^{58}$ Moreover, it has high affinity towards FA receptors which aremainly overexpressed in breast (MCF-7), and cervical (KB) cells. ${ }^{59}$ Gold nanoparticle conjugated generation five dendrimers (Au : G5D) and $\mathrm{Au}$ : G5D:FA NPs proved to be highly efficient in combining with pCMV-Luc DNA and transporting it. The pDNA were safeguarded from nucleases corresponding to formation of stable nanocomplexes. ${ }^{60}$ siCOX-2/9R/DG-AuNS (hydrazone) showed best gene silencing and inhibition effect on tumor cell growth amongst siCOX-2/AuNS, siCOX-2/9R-AuNS, siCOX-2/9R/ DG-AuNS, and siCOX-2/9R/DG-AuNS (hydrazone) groups in both HepG2 and SGC7901 cells. ${ }^{61}$ In comparison to free siRNA,

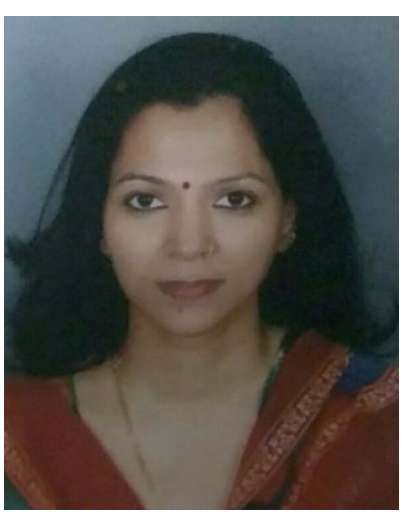

Dr Shefali Shukla has been working as an Assistant Professor in Department of Chemistry, Sri Venkateswara College, University of Delhi since 2005. She did her graduation from Delhi University, postgraduation from Indian Institute of Technology Delhi and completed her PhD in the field of organic chemistry, from University of Delhi in 2002. Her research interests include derivatization of alkaloids and anti-cancer activity studies. Also, she has worked on anti-tubercular activity studies of coumarins and synthesis and activity studies of chalcones. Currently she is focusing on the anti-cancer properties of the nanoparticles.

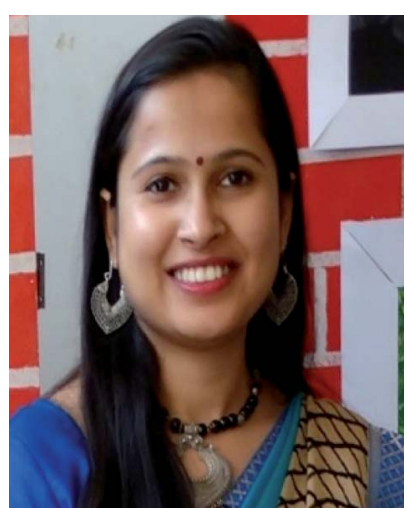

Dr Akanksha Gupta has been working as an Assistant Professor in the Department of Chemistry, Sri Venkateswara College, University of Delhi since 2017. She did her PhD in the field of Materials Chemistry from University of Delhi in 2017. She is expertise in synthesis and crystallographic studies of mixed metal oxides along with their applications. Currently, she is focusing in the field of nanotechnology, anti-cancer agents and bio-inorganic chemistry. 


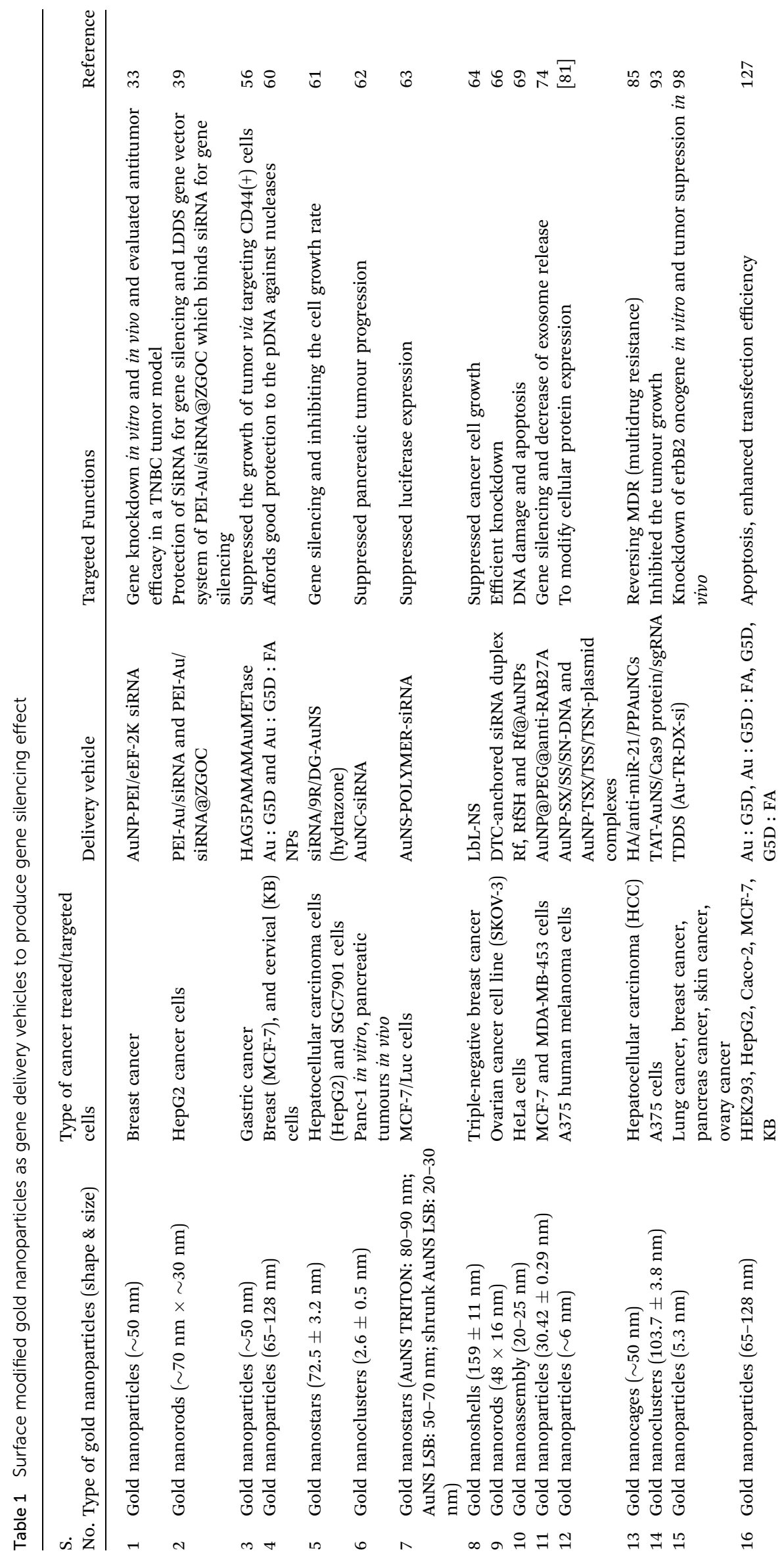




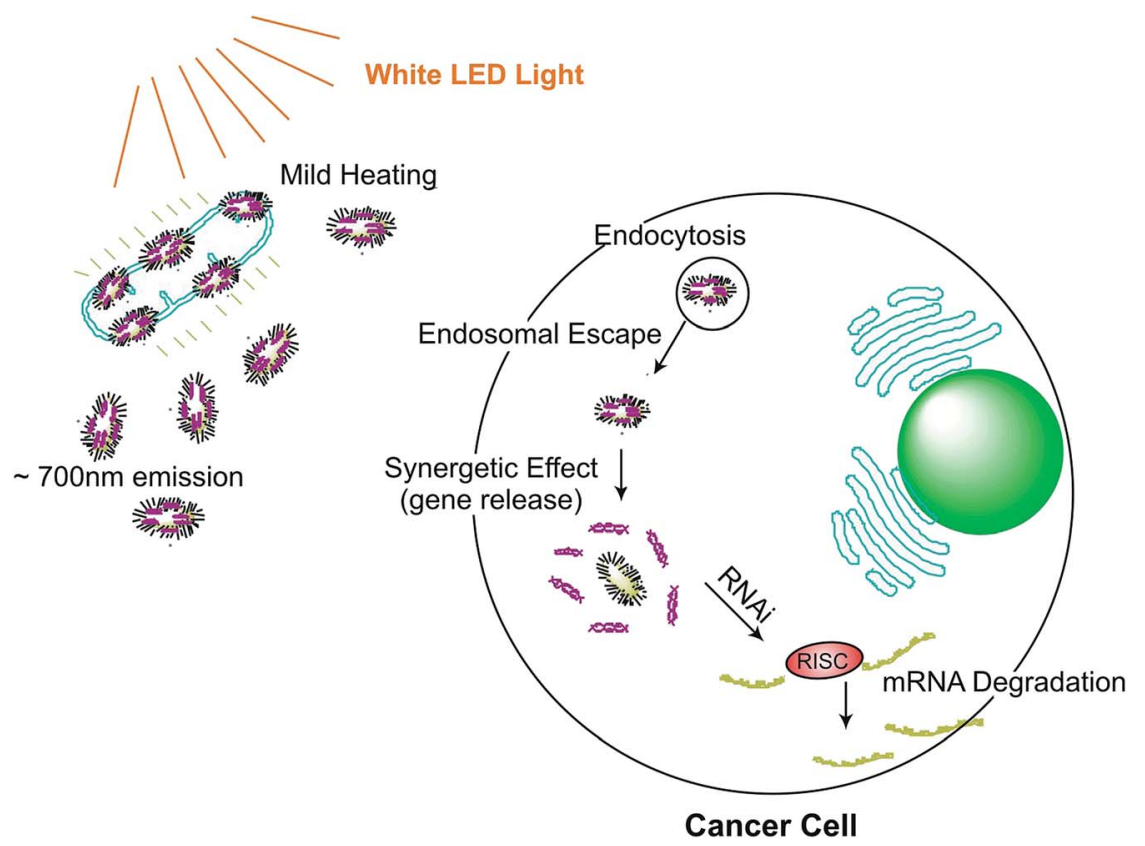

Fig. 1 Gene silencing on targeted cancer cell site using white LED light ( $700 \mathrm{~nm}$ emission). Gold nanorods-assembled $\mathrm{ZnGa}_{2} \mathrm{O}_{4}-\mathrm{Cr}$ nanofibers for LED-amplified gene silencing. ${ }^{39}$

gold nanocages conjugated siRNA (AuNC-siRNA) entered the Panc-1 cells in much larger quantity, showed lysosomal escape and effective gene silencing. In addition, it enhanced circulation lifetime, increased accumulation on tumour sites showed high safety. ${ }^{62}$ PPE-LA coating showed better gene silencing of MCF-7 cells than AuNS (gold nanostar) coated with $\mathrm{SH}^{-}$ PEG3000-NH $\mathrm{N}_{2}$. Although, siRNA complexes coated with AuNS showed better results than siRNA alone. ${ }^{63}$ Using Western blotting, it was analysed that miR-34a-LbL-NS significantly decreased Bcl-2 and SIRT1 expression in MDA-MB-231 cells in comparison to control groups and also reduced metabolic activities in MDA-MB-231 cells. ${ }^{64}$ Transglutaminase 2 (TG2) plays a vital role in metastasis of recurrent ovarian cancers, hence becomes a critical target. ${ }^{65}$ Successful gene knockdown by AuNR based DTC-siRNA, was observed using colorimetric assay ${ }^{66}$ Flavoprotein enzyme assembling is done mainly by riboflavin (Rf) and is overexpressed in prostate and human breast cancers. ${ }^{67,68}$ Abhishek Sau and team prepared thiolmodified riboflavin-gold nanoparticles (RfS@AuNPs), targeting HeLa cells hence causing DNA damage and apoptosis in them. ${ }^{69}$ Exosomes which are found in body fluids, containing protein and nucleic acids, secreted by both normal and malignant cells. ${ }^{70-72}$ The presence of these in higher content is responsible for tumour growth and evasion..$^{7,73}$ AuNP@PEG@anti-RAB27A silence higher gene expression than that of RAB27A, also inhibiting formation of Rab27, a protein

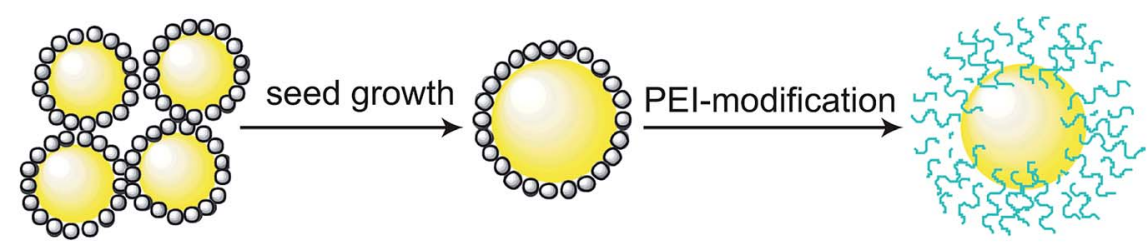

seed gold nanoparticles

hydrodynamic diameter

hydrodynamic diameter of 54 hydrodynamic diameter $21 \pm \quad 51 \pm 0.3 \mathrm{~nm}$ $\pm 0.45 \mathrm{~nm}$ $2 \mathrm{~nm}$
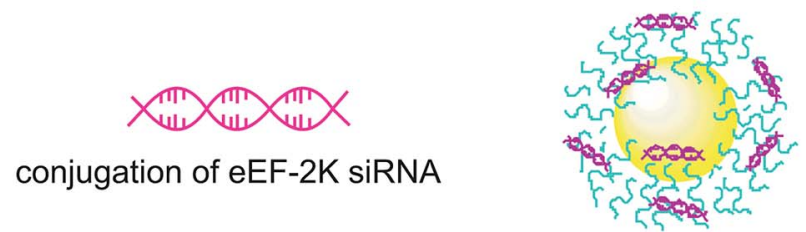

eFEF-2K siRNA conjugated AuNP

(AuNP-PEl/eEF-2K siRNA)

Fig. 2 Schematic illustration for modification of AuNPs via polyethyleneimine. ${ }^{33}$ 
Table 2 Characterization of AuNPs for enhanced gene delivery

\begin{tabular}{lllll}
\hline S. no. & $\begin{array}{l}\text { Type of gold nanoparticles } \\
\text { (shape \& size) }\end{array}$ & Type of cancer treated & Delivery vehicle & Targeted functions \\
\hline 1 & $\begin{array}{l}\text { Gold nanorods } \\
(\sim 30 \mathrm{~nm} \times 10 \mathrm{~nm})\end{array}$ & HEK293, HepG2 cells & $\begin{array}{l}\text { AHP, sm-AHP, } \\
\text { CD-PGEA } \\
\text { Au DENPs-mPEG } \\
\text { and Au DENPs-PEG-FA }\end{array}$ & $\begin{array}{l}\text { Apoptosis, enhanced transfection } \\
\text { efficiency }\end{array}$ \\
$\begin{array}{l}\text { Gold nanoparticles } \\
(2.9 \mathrm{~nm} \text { and } 3.1 \mathrm{~nm})\end{array}$ & EGFP, Luc cells & Reference \\
\end{tabular}

from RAB27A mRNA. ${ }^{74}$ Xinyan Chen et al. used "ship in a bottle strategy" and encapsulated AuNRs inside the hollow cavity of HSN (hollow silica nanoparticles). SF (hydrophobic antiproliferative and antiangiogenic drug) release was observed due to the detachment of CD-PGEA when NIR radiation was applied, leading to apoptosis in both in vitro as well as in vivo. ${ }^{75}$

\section{Analyzing targeted gene delivery using modified gold nanoparticles}

The main goal of gene therapy is to select an acceptable carrier to specifically transport the target gene to the desired target cell and promote its effective expression for treatment. The carrier of gene therapy mainly includes two categories: viral vector and non-viral vector. ${ }^{56}$ Surface-modified Gold nanomaterials are considered as efficient gene delivery vehicles. ${ }^{76,77}$ However, for gene therapy in general, siRNA molecules are phagocytosed and hence need to overcome extracellular and intracellular obstacles and be released from the endosome after being internalized by tumor cells. ${ }^{78}$ Scientists have reported the efficiency of gold nanoparticles in analyzing targeted gene delivery and these are summarized in Table 2 . The Covalently coupled nucleic acids (such as single monodentate thiol (SX), bidentate dual thiol (SS), or mixed bidentate thiol plus amine (SN) coordination of nucleic acids) on the surface of gold nanoparticles (AuNP) have been used as an effective gene therapy agent to modify cellular protein expression. It is anticipated that the therapeutic effect depends on length of time the nucleic acid sequence resides in the endo-lysosomal pathway once the cell is transfected. It is believed that it depends on the linkage chemistry of the DNA to the AuNP surface. ${ }^{79}$ LDDSs, which are designed to manipulate the tumor microenvironment are normally injected (or implanted), have intrinsic drawbacks in achieving effective gene therapy. Therefore, by combining LDDSs and particulate gene carriers (i.e. gold nanorods) unique opportunities might be offered allowing controlled delivery and release of a targeted therapeutic concentration and effective phagocytosis of siRNA molecules for enhanced gene therapy. Polyethyleneimine (PEI) is a well-known non-viral nucleic acid vector with high transfection efficiency both in vitro and in vivo due to the high density of positively charged amino groups distributed along the backbones of the molecular chains. ${ }^{80}$ The positively-charged polyethyleneimine conjugated gold nanorods (Au-PEI NRs) possess the ability to electrostatically bind to negatively-charged siRNA. The protection of siRNA by PEI-Au/siRNA and PEI-Au/ siRNA@ZGOC vectors was further verified by the addition of
RNaseA to mimic the human serum environment. The PEI-Au/ siRNA and PEI-Au/siRNA@ZGOC vectors were found to protect the siRNA, effectively, from the degradation effects of RNaseA. ${ }^{39}$ The permeability barrier imposed by stratum corneum makes an extreme challenge for the topical delivery of plasmid DNA (pDNA), which is widely used in gene therapy. ${ }^{81}$ Dendritic macromolecules are highly branch monodisperse macromolecules, presenting a sphere with cavity structure, hence are easy to combine with DNA to form nanoscale complex, which can protect DNA to achieve the purpose of transfection, so as the viral carrier, which is widely used..$^{82} \mathrm{~A}$ group of researchers performed surface modification on polyamidoamine (PAMAM) dendrimers to decrease cytotoxicity and increase transfection efficiency ${ }^{83}$ Hyaluronic acid (HA), with good biocompatibility and aqueous solubility, was reported to be a receptor of $\mathrm{CD} 44 .{ }^{84}$ HA can target the site with high-expression CD44 tumor for targeted drug delivery to CD44-overexpressing cancer cell. ${ }^{46} \mathrm{~A}$ novel gene delivery vector was developed, hyaluronic acid (HA)modified, polyethylenimine (PEI)-conjugated PEGylated gold nanocages (AuNCs), which was designated as HA/PPAuNCs. This system possessed relative high photothermal conversion efficiency upon near infrared (NIR) laser irradiation, low cytotoxicity, and high targeted delivery ability. Moreover, anti-miR21 could be condensed by PEI onto the surface of HA/PPAuNCs and then delivered into target cells. Therefore, HA/anti-miR-21/ PPAuNCs might effectively overcome DOX resistance of HCC and provide new insights for cancer treatment. ${ }^{85}$

\subsection{Employing gold nanoparticles for gene delivery in vitro}

Various scientists have studied the role of AuNPs in vitro to improve gene delivery in a targeted manner. In this context, modification of AuNPs with cationic polymers bound effectively to negatively surface charged siRNA molecules via a layer-bylayer approach has been studied. Due to their unique combination of surface plasmon properties and nanometer-scale dimensions, effective intracellular delivery of Au nanoparticles can be achieved along with transfected siRNA in vitro. ${ }^{39}$ Presently, using multifunctional carrier AuNP, the perforation and transfection effect of pDNAs in the melanoma cells at the subcutaneous site were investigated. ${ }^{81}$ Polyethyleneimine (PEI) having abundant surface amine groups is found to be showing high efficacy due to its ability to compact DNA efficiently, ${ }^{86,87}$ however it has high levels of cytotoxicity. Hence, PEG has been used along with gold nanoparticles targeting HeLa. ${ }^{88}$ Cyclooxygenase-2 (COX-2) is a rate-limiting enzyme overexpression of which is a sign of tumorigenesis, promotion of 
malignant tumor cells and is expressed in vascular endothelial and adjacent normal tissues. ${ }^{\mathbf{8 9} 90}$ Hongyan Zhu et al. have prepared siCOX-2/AuNS, siCOX-2/9R-AuNS, siCOX-2/9R/DGAuNS, and siCOX-2/9R/DG-AuNS (hydrazone) groups in combination with siRNA to down-regulate COX-2 expression, targeting HepG2 (hepatocellular carcinoma cells) and SGC7901 cells. ${ }^{61}$ Plk1 gene is overexpressed in many tumor tissues for e.g., A375 cells, inhibition of which is a good strategy for tumor therapy. ${ }^{91,92}$ Peng Wang et al. prepared LGCP (polyethylene glycol-lipid/AuNS/Cas9 protein/sgPlk1 plasmid) to suppress Plk1 gene. ${ }^{87}$ The folate receptor (FR) is overexpressed in abundant of cancers such as: human ovarian, brain, cervical, epithelial, and breast cancer amongst others. ${ }^{\mathbf{9 4}}$ Jude Akinyelu and Moganavelli Singh prepared folic acid (FA) and chitosan (CS) functionalization with Au-PLGA NPs for downregulation of FR. ${ }^{95}$ Heregulin-2 (HER2) is overexpressed in human ovarian cancer cell line and are known to be resistant to chemotherapy and aggressive. ${ }^{96,97}$ Rajesh Kotcherlakota and team prepared TDDS (Au-TR-DX-si) to target the same. ${ }^{98}$ Pancreatic cancer being one of the dangerous cancers, its prominent cause being perineural invasion has its adverse effects such as increased neurite densities. ${ }^{\mathbf{9 9 , 1 0 0}}$ Targeting NGF gene is the most important to tackle pancreatic cancer. ${ }^{62}$ Hence, Yifeng Lei et al. synthesized AuNC-siRNA ${ }^{62}$ because siRNA has the ability to cause sequence-specific gene silencing. ${ }^{\mathbf{1 0 1 , 1 0 2}}$ Carla Sardo and team used a different shape of gold nanoparticle, i.e., gold nanostar and conjugated it with SH-PEG3000-NH2 and PPE-LA targeting MCF-7/Luc cells. ${ }^{63}$ As depicted in Table 2, AHP has shown better transfection efficiency than sm-AHP in HEK293 and HepG2 cells, which was visualized using enhanced green fluorescent protein (EGFP). This could be due to the shape and size of gold nanorods, and also rough surface of AHP. ${ }^{75}$ miRNA regulates gene expression to control cell metabolic activity. ${ }^{103}$ In an experiment conducted by R. Goyal et al., LbL-NS was developed to deliver miR-34a into triple-negative breast cancer cells. ${ }^{64}$ Poly-L-lysine (PLL) shows good endosomal escape, ${ }^{104}$ since loss of expression of miR-34a takes place in TNBC. ${ }^{\mathbf{1 0 5 , 1 0 6}}$ Therefore, naked miRNA cannot passively target due to its large size and negative charge. ${ }^{\mathbf{1 0 7}}$ In a study carried out by Jianxin Wang et al., DTC-anchored siRNA duplex loaded onto AuNRs was used, which targeted ovarian cancer cell line (SKOV-3). DTC (dithiocarbamates) are resistant to nonspecific desorption reducing off target effects. ${ }^{66}$ Nucleic acid is a great tool for detection as well as treatment purposes. ${ }^{\mathbf{1 0 8 , 1 0 9}}$ MicroRNA (miRNA) plays vital roles in cell proliferation, differentiation, ${ }^{110,111}$ and tumors, ${ }^{112,113}$ and one of it's example is Lethal-7 (Let-7). ${ }^{114}$ One of its members is Let-7a which can suppress the tumor cell growth and metastasis. ${ }^{115,116}$ Although DNA and RNA are similar compounds, a major difference is in their structure. DNA contains only one hydroxyl group, while RNA contains two hydroxyl groups. So, PBA shows low binding effect for compounds containing one hydroxyl group. ${ }^{117}$

Isocitrate dehydrogenase 1 (IDH1) which is highly expressed in Glioblastoma multiforme (GBM) is disruptive form found in brain tumors and can be targeted using siRNA. ${ }^{118,119}$ Jun Yue et al., modified the siRNA with AuNPs (stars and spheres) to target the Isocitrate dehydrogenase 1 (IDH1) expression. ${ }^{\mathbf{1 2 0}}$ The
$\mathrm{N} / \mathrm{P}$ ratio of 2.5 reveals the best transfection efficiency which was observed using flow cytometry and confocal microscopy. It could be due to the compaction ability and strong interaction of vectors with pDNA. ${ }^{142}$

Baoji Du et al., have used GDD (gold nanoparticles/ dimethyldioctadecylammonium bromide (DODAB)/ dioleoylphosphatidylethanolamin) and GF (gold nanoparticles/DODAB/DOPE/DOPE-folic acid) with different ratios of DOPE-FA targeting MCF-7 and A549 cells both in vitro and in vivo which is portrayed in the above figure ${ }^{121}$

\subsection{In vivo delivery of genes via gold nanoparticles}

The emerging need to explore recent nanoparticles capable of altering the collective state is worthy of attention; ${ }^{122}$ that is, how such vehicles can be modified for the development of in vivo obstacles that AuNPs face. ${ }^{123}$ Previously, the interaction of small AuNPs with DNA was studied at low [ $\mathrm{NaCl}]$, concluding that the reversible groove binding interaction was governed by solvation and viscosity factors. ${ }^{\mathbf{1 2 4}}$ Recently, in the study of the structural characterization of the gold colloid-DNA interaction, it was shown that AuNPs was able to interact with DNA via groove binding or intercalation, depending on the ethanol content and the $R$ ratio. ${ }^{\mathbf{1 2 5}}$ According to Elia et al. previous structural approach, ${ }^{\mathbf{1 2 5}}$ their study has demonstrated that ethanol modifies AuNPs/DNA interaction from intercalation to groove binding by two simple mechanisms: gold nanoparticle aggregation and change in DNA conformation from $\mathrm{B}$ to $\mathrm{C}-$ form. ${ }^{\mathbf{1 2 6}}$ Particulate systems can be associated with the circulation of excessively high concentrations of drugs in vivo. (LDDSs) offer the potential to target the drug more effectively. ${ }^{127}$ In their work, Xiang et al. reported a new type of localized gene delivery system with LED-responsive properties based on the combination of the LDDSs and nanoparticle gene vectors. In their system, hTERT siRNA was grafted on to AuNRs and these were attached to the surface of electrospun ZGOC nanofibers as depicted in Fig. 3. $\mathrm{Au}$ nanorods with an absorption peak of $700 \mathrm{~nm}$ matching the emission of ZGOC nanofibers were prepared using a seed growth method. Gold nanorods modified with a cationic polymer (PEI) were electrostatically bound with negatively charged siRNA. ${ }^{39}$

To facilitate the skin penetration of pDNA deeply into the melanoma tissues, Jiang et al. presented a cell penetrating peptide and cationic polymer (PEI) conjugated gold nanoparticle (AuNP) that can compact the pDNAs into cationic nanocomplexes and penetrate through the intact stratum corneum without any additional enhancement used. Moreover, the AuNP is highly efficient in stimulating the intracellular uptake and nuclear targeting of the pDNAs in cells, which guarantees the effective transfection. It was shown that not only miR-222 but also miRNA-221 reduces viability and induce apoptosis mediated by the KIT, AKT and BCL2 signaling cascade. ${ }^{128}$ miRNA-221 has been proposed as a potential tumor suppressor for melanoma therapy. Moreover, topical delivery miRNA-221 inhibitor gene can avoid or decrease reticulo endothelial system (RES) uptake, reduce systemic toxicity, and provide targeted gene delivery to the tumor site located at the skin 


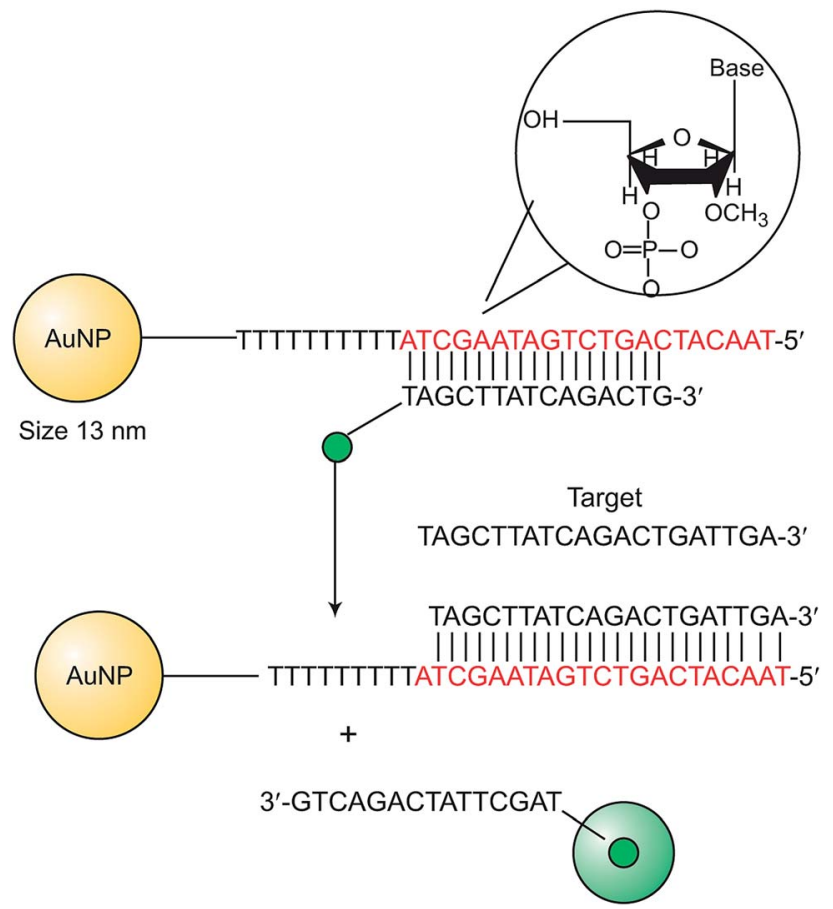

Fig. 3 Schematic representation for miRNA detection using AuNP $2^{\prime}$-OMe-DNA probes. ${ }^{57}$

subcutaneous layer. However, stratum corneum always poses a formidable challenge to biomacromolecules penetration. To circumvent these problems that confront the current methods, herein, for the first time, they presented a novel strategy for the cutaneous melanoma therapy by topical delivery a pDNA encoded with miRNA-221 inhibitor gene through HIV-1 twinarginine translocation peptide (TAT) conjugated cationic gold nanoparticles. ${ }^{33}$

\section{Combinatory therapies in cancer treatment using modified gold nanoparticles}

In general, ideal non-viral gene vectors offer characteristics, such as chemical stability, biocompatibility, effective targeting, stimulus responsiveness and feasibility for combined treatments (i.e. chemotherapy, photothermal therapy, photodynamic therapy, etc.). ${ }^{\mathbf{3 8 , 7 8 , 1 4 4}}$ Gene delivery vectors reported in the recent years, include polymer-based, lipid-based, and inorganic nanoparticle-based $\quad$ systems. ${ }^{\mathbf{1 2 9 , 1 3 0}}$ Surface-modified Au nanomaterials are recognized as promising gene delivery vehicles. ${ }^{76,77}$ The anti-cancer effects of the PEI-Au/siRNA and PEI-Au/ siRNA@ZGOC samples were assessed via in vitro cell culture for $48 \mathrm{~h}$ and $72 \mathrm{~h}$, using exposure to LED light. LED radiation did not appear to induce any clear effect on the PEI-Au/siRNA group but, in contrast the PEI-Au/siRNA@ZGOC group showed a significant decrease in cell viability under LED irradiation. ${ }^{\mathbf{1 1}}$ pAuNPs revealed to have high photothermal effect and loading capacity by Au-thiol linkage. Hence, FAM-Dz/TAT-pAuNPs was prepared to target hepatitis $\mathrm{C}$ virus (HCV) human hepatocarcinoma cells using hyperthermic treatment via photothermal therapy. The loading was successful which proved to be biocompatible and resulted in low cytotoxicity. ${ }^{131}$ Combinatorial approach using gene therapy and chemotherapeutic drugs has been successfully done in combination with AuNPs which successfully lead to tumor suppression and ErbB2 gene silencing. ${ }^{98}$

\section{Role of modified gold nanoparticles in detection and imaging of tumors}

One of the major aspects in treating cancer is accurate detection and imaging of oncogenic cells which enables various therapeutic techniques to eliminate them effectively, many of which are discussed in Table 3. Various gold nanoparticles of different shapes like, gold nanospheres and sizes have been depicted, which illustrate the cellular uptake by cell lines. Cellular uptake is usually observed using confocal microscopy, flow cytometry, Western blot analysis, TEM. Deep tissue imaging with a long period has been achieved in vivo using repeated excitation with low-energy LEDs. ${ }^{\mathbf{1 3 2 - 1 3 4}}$ Several cellular uptake detections can be done using the confocal laser scanning microscopy (CLSM) as mentioned in few examples. A comparison between the cellular uptake of PEI and PEG-Au PENPs has been done using the confocal laser scanning microscopy (CLSM), proving that L25/ pDNA polyplex has almost the same cellular uptake as that of PEI/pDNA polyplex. ${ }^{88}$ Also, siRNA/9R/DG-AuNS (hydrazone)treated cells showed greater fluorescence intensity amongst AuNS, 9R-AuNS, 9R/DG-AuNS and 9R/DG-AuNS (hydrazone). ${ }^{61}$ LGCP was successfully detected using confocal microscopy indicating the successful endosomal escape of the LGCP as the separation of the green/red fluorescence from the blue fluorescence took place. ${ }^{93}$ Transfection analysis of FA-CS-PLGA NPs, CS-PLGA NPs, Au-CS-PLGA NPs and FA-Au-CSPLGA NPs only to be proven that $\mathrm{Au}$ functionalized has high cellular uptake than

Table 3 Detection and imaging of tumor cells via modified gold nanoparticles

\begin{tabular}{|c|c|c|c|c|c|}
\hline S. no. & Type of gold nanoparticles (shape \& size) & Type of cancer treated & Delivery vehicle & Inference & Reference \\
\hline 1 & Gold nanoparticles (L25, L50, L100, L200) & HeLa cells & PEG-Au PENPs & L25 has high cellular uptake & 88 \\
\hline 2 & Gold nanoparticles $(199.4 \pm 25.2 \mathrm{~nm})$ & $\begin{array}{l}\text { MCF-7, HepG2 and } \\
\text { HEK293 cells }\end{array}$ & $\begin{array}{l}\text { Au-CS-PLGA NPs } \\
\text { and FA-Au-CSPLGA NPs }\end{array}$ & High cellular uptake & 95 \\
\hline 3 & $\begin{array}{l}\text { Gold nanosphere }(\sim 13 \text { and } 50 \mathrm{~nm}), \text { star } \\
(\sim 40 \mathrm{~nm})\end{array}$ & U87 cells & SiRNA & High cellular uptake & 118 \\
\hline 4 & Gold nanoparticles $(\sim 10 \mathrm{~nm})$ & MCF-7, A549 cells & GDD, GF & Enhanced cellular uptake & 119 \\
\hline
\end{tabular}



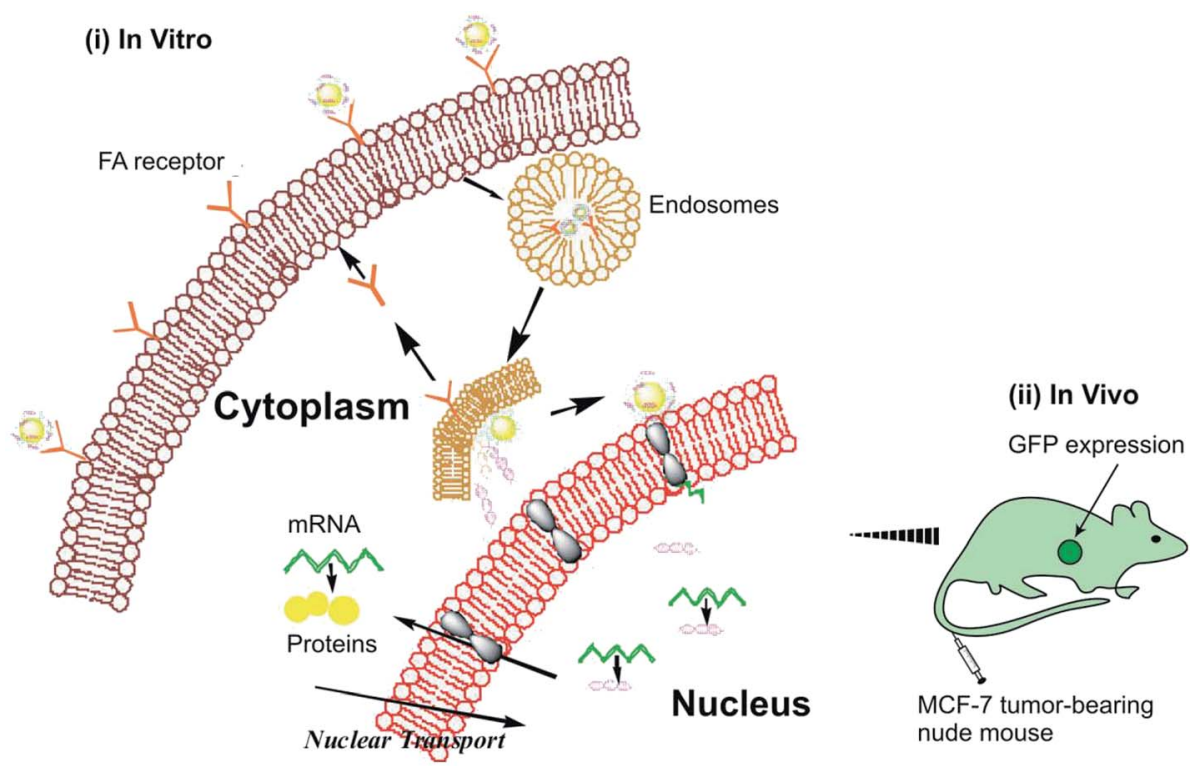

Fig. 4 Depiction of targeted gene delivery of GF/DNA (i) in vitro and (ii) in vivo. ${ }^{121}$

others because it has high atomic number hence easily identified using TEM. ${ }^{135}$ Also it has high zeta potential indicating its stability and increased adsorption of FA and chitosan onto the PLGA. ${ }^{60}$ Direct sequencing method which is used for traditional detection of gene mutations has various setbacks such as complexity, time-consuming, and expensive. ${ }^{136,137}$ So in an experiment done by Xihong Zhao and Chii-Wann Lin., they used colorimetric assays to detect various PNA/DNA complex in AuNPs solution. When PNA is added, colour of the AuNP solution changes from brick-red wine colour to dark purple, on addition of PNA-DNAcomp complex it retains its colour back to brick-red wine colour, and on adding PNA-DNAnc mixture it shows purple colour. ${ }^{138}$ Furthermore, Rajesh Kotcherlakota et al., used confocal microscopy to detect the effect of TDDS on SKOV-3 (HER2+) and MDA-MB-231 (HER2-) cells. ${ }^{98}$ Endosomal escape was also observed using TEM. ${ }^{98}$ Siyu Qian et al., reported an experiment in which they used PBA-AuNPs for detection of miRNA using SPR sensing system as illustrated in Fig. $4 .{ }^{139}$ RNA induces low response in SPR detection as it has lower mass, hence AuNPs are used to produce effective results for detection as it has high mass. ${ }^{140,141}$

Western Blot and Nano Tracking Analysis (NTA) were the techniques used for AuNP@PEG@anti-RAB27A to evaluate the exosomes release. Consequence of it was the reduction of exosomes secretion and also exported the nanoparticles to recipient cells, hence decrease of the exosome release. ${ }^{74}$ Confocal microscopy and flow cytometry (FCM) were used to evaluate the gene transfection abilities of GDD and GFs. ${ }^{119}$ Results showed that GF2.5 showed higher gene transfection efficiency for MCF7 cells due to enhanced cellular uptake efficiency mediated by the FA targeting ability, but did not so in A549 (FA-receptornegative cells) (Fig. 5 and 6). ${ }^{119}$

Confocal microscopy and flow cytometry were used to assess the cellular uptake of both Au DENPs-mPEG and Au DENPsPEG-FA, implying that FA modification and enhanced the cellular uptake. ${ }^{142}$ EGFP (Enhanced green fluorescent protein) was performed to visualize the gene transfection of AHP in HepG2 cells, hence demonstrating it to have highest

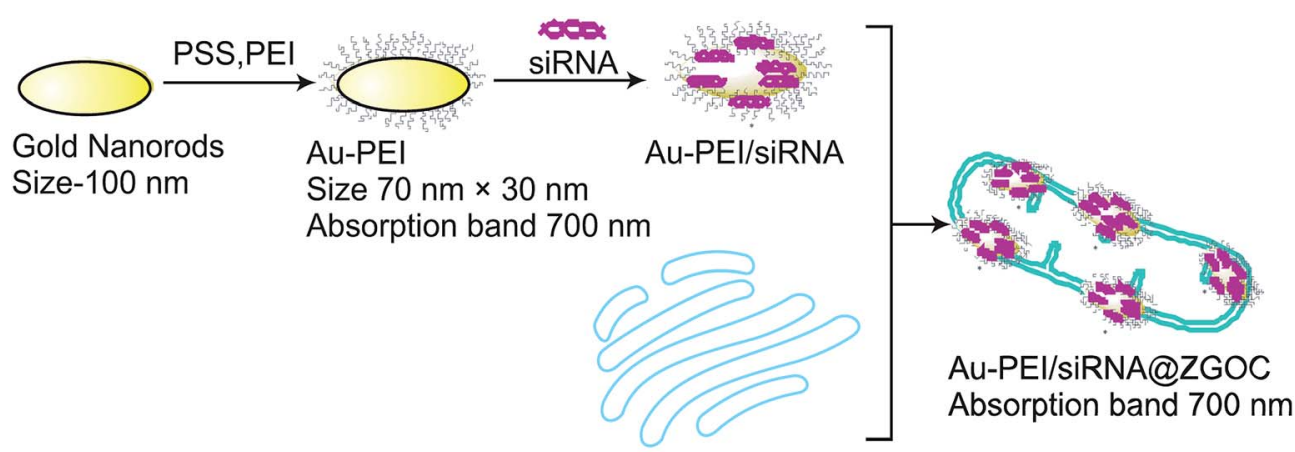

ZGOC Nanofibers

Fig. 5 Schematic illustration of PEI-Au/siRNA onto ZGOC nanofibers. ${ }^{39}$ 


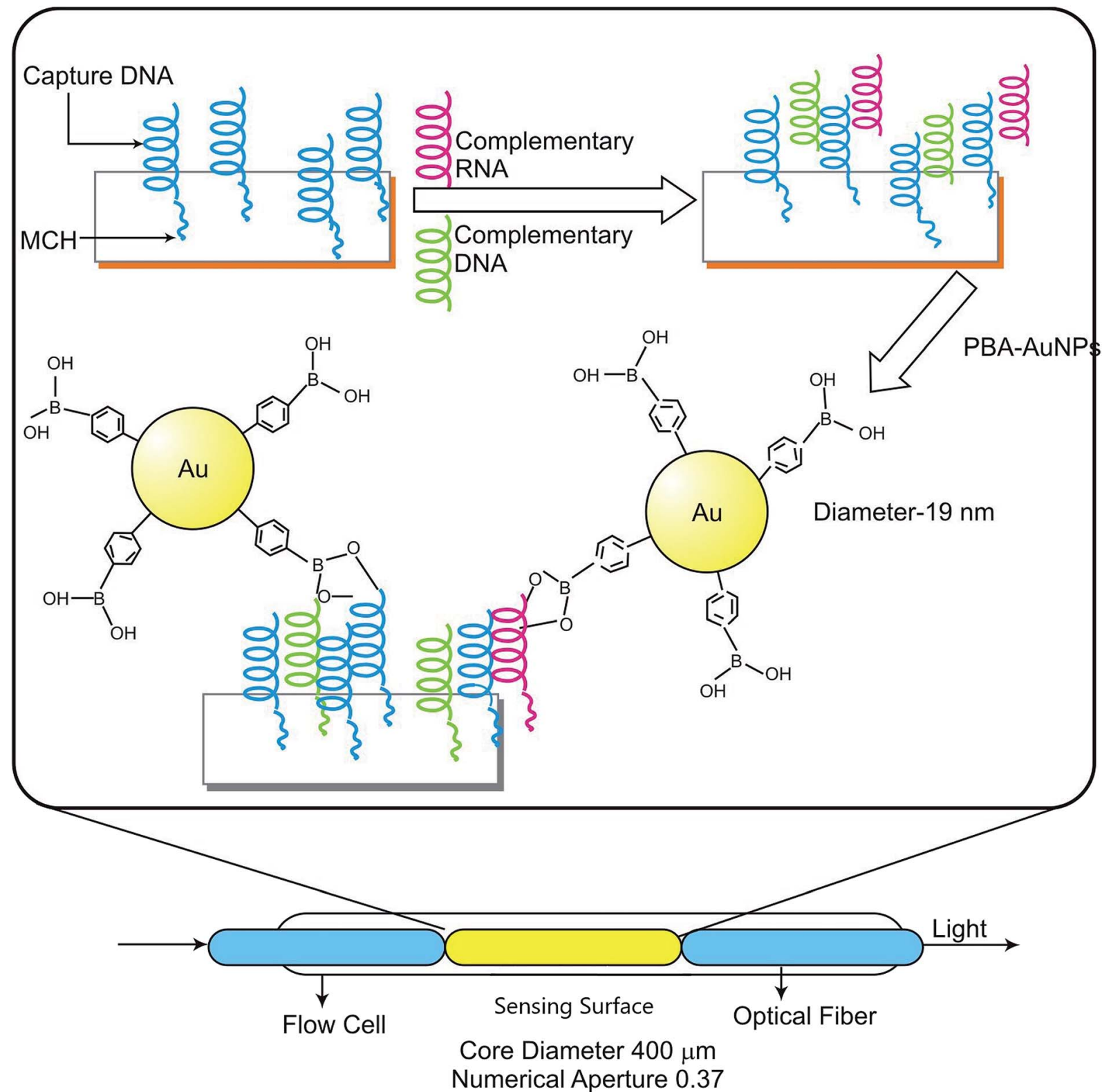

Fig. 6 Combinatory therapy representing schematic illustration of SPR sensing system for detecting miRNA. ${ }^{139}$

transfection amongst CD-PGEA and PEI. ${ }^{75}$ Also, flow cytometry assay was used to further evaluate the cellular uptake and revealed AHP to have the highest trends. ${ }^{75}$

\section{Cytotoxic assays of gene delivery vectors on healthy cells}

The detection of cytotoxic effects of gene vectors and nanoparticles for both tumor and normal cells is critical for their translation to clinics. This indicates biocompatibility of gene delivery vehicles and nanoparticles for gene delivery. Haematological and biochemical parameters are main indicators to assess the cytoxic effects of nanoparticles. Various methods for detection of cytotoxicity levels are MTT assay, cell counting kit-8
(CCK-8), cell viability test, and many more. Moreover, the HA-G5 PAMAM-Au-METase could markedly inhibit the tumor sphere formation rather than HA-G5 PAMAM-METase. ${ }^{56}$ The cytotoxicity assay in an experiment conducted by Aijun Li and team was carried out using Cell Counting Kit-8 (CCK-8) assay, proving that polyethylenimine (PEI) alone is more cytotoxic than PEG$\mathrm{Au}$ PENPs at different concentrations. Cytotoxic levels were found to be in the order PEI $>$ L25 $>$ L50 $>$ L100 $>$ L200 ${ }^{88}$ Another method used is detection using MTT reduction assay showing that all FA-CS-PLGA NPs, CS-PLGA NPs, Au-CS-PLGA NPs and FA-Au-CSPLGA NPs are non-toxic. ${ }^{95}$ MTT assay tested the cytotoxicity of Au : G5D : DNA, Au : G5D : FA : DNA, G5D : DNA and G5D : FA : DNA and found Au : G5D : DNA, Au : G5D : FA : DNA to be less toxic than G5D : DNA and G5D : FA : DNA. ${ }^{60}$ MTT assay was used to evaluate the cytotoxicity of GDD and GFn, 
Table 4 Various other combinatory characteristic features of gold nanoparticles

\begin{tabular}{|c|c|c|c|c|c|}
\hline $\begin{array}{l}\text { S. } \\
\text { No. }\end{array}$ & $\begin{array}{l}\text { Type of gold nanoparticles } \\
\text { (shape \& size) }\end{array}$ & $\begin{array}{l}\text { Type of cancer } \\
\text { treated/targeted cells }\end{array}$ & Delivery vehicle & Targeted Functions & Reference \\
\hline 1 & $\begin{array}{l}\text { Gold nanoparticles }(13 \mathrm{~nm} \pm 2 \\
\mathrm{nm})\end{array}$ & Breast cancer & AuNP-2'-OMe-DNA probes & $\begin{array}{l}\text { miRNA-21 detection and } \\
\text { inhibition leading to apoptotic } \\
\text { cells death }\end{array}$ & 57 \\
\hline 2 & Gold nanoplates & $\begin{array}{l}\text { HCV genomic human } \\
\text { hepatocarcinoma }\end{array}$ & TAT/FDz-pAuNPs & $\begin{array}{l}\text { To investigate the synergistic } \\
\text { effect of NIR irradiation with } \\
\text { pAuNPs-based chemotherapy }\end{array}$ & 123 \\
\hline
\end{tabular}

GF2.5 demonstrated to be least cytotoxic. ${ }^{119}$ CCK-8 assay was used to evaluate the cell viability of non-viral vectors indicating the reduction of cytotoxicity using both Au DENPs-mPEG and Au DENPs-PEG-FA. ${ }^{142}$ Using MTT assay it was evaluated that cell viabilities of HEK293 and HepG2 cell lines was above $\approx 60 \%$, suggesting the compromised cytotoxicity of AHP. ${ }^{75}$ Many combinatory aspects of employing AuNPs are depicted in Table 4.

\section{Conclusion}

Gene therapy is a tool for treatment of cancer and genetic diseases. In this review, recent research work done in the field of cancer treatment using gene therapy, via surface modified gold nanoparticles has been discussed. There are numerous more therapies like radiotherapy, chemotherapy, immunotherapy, targeted therapy, and hormone therapy. For future prospects, these therapies in combination with gene therapy have better and safer treatments against cancer. Combinatory therapies along with gene therapy using AuNPs as delivery vehicles can be used effectively for the treatment of cancer since most cancers are recurring or have become immune to single therapies used. Also, therapies like chemotherapy and radiotherapy have various side effects which in synergy with gene therapy could reduce their cytotoxicity. Viral and non-viral vectors are commonly used for transfection of therapeutic genes to tumor. Since, viral vectors have less loading capacity, limited mass production, are cytotoxic and show strong unwanted immune activity. Hence, non-viral vectors have wider scope in the future. Their advantages include low cytotoxicity, good binding ability to nucleic acids, nucleic acids release controlling ability, strong binding efficiency to nucleic acids and high cellular uptake. Transfections of nucleic acids and various biomolecules in conjugation with gold nanoparticles to tumor sites have proven to inhibit tumor growth. This suggests the translational approaches toward cancer gene therapy via gold nanostructures. Higher cellular uptake, biocompatibility, low cytotoxicity and detection are some of the parameters required for biomolecules as well as gold nanoparticles for translation to clinics. Currently, some of the liposome based nanoparticles are in clinical trials for gene silencing.

\section{Conflicts of interest}

There are no conflicts to declare.

\section{References}

1 S. Duarte, G. Carle, H. Faneca, M. C. P. de Lima and V. Pierrefite-Carle, Cancer Lett., 2012, 324, 160-170.

2 H. J. Kim, A. Kim, K. Miyata and K. Kataoka, Adv. Drug Deliv. Rev., 2016, 104, 61-77.

3 H. Kim and W. J. Kim, Small, 2014, 10, 117-126.

4 C. Ma, L. Shi, Y. Huang, L. Shen, H. Peng, X. Zhu and G. Zhou, Biomater. Sci., 2017, 5, 494-501.

5 S. Rietwyk and D. Peer, ACS Nano, 2017, 11, 7572-7586.

6 M. W. Amjad, P. Kesharwani, M. C. I. Mohd Amin and A. K. Iyer, Prog. Polym. Sci., 2017, 64, 154-181.

7 J. Li, C. W. T. Leung, D. S. H. Wong, J. Xu, R. Li, Y. Zhao, C. Y. Y. Yung, E. Zhao, B. Z. Tang and L. Bian, ACS Appl. Mater. Interfaces, 2019, 11(25), 22074-22084.

8 D. Lee, K. Upadhye and P. N. Kumta, J. Mater. Sci. Eng. B, 2012, 177, 289-302.

9 C. Zhang, Y. Yong, L. Song, X. Dong, X. Zhang, X. Liu, Z. Gu, Y. Zhao and Z. Hu, Adv. Healthcare Mater., 2016, 5, 27762787.

10 D. Bumcrot, M. Manoharan, V. Koteliansky and D. W. Sah, Nat. Chem. Biol., 2006, 2(12), 711-719.

11 R. Shahbazi, B. Ozpolat and K. Ulubayram, Nanomedicine, 2016, 11(10), 1287-1308.

12 B. Ozpolat, A. K. Sood and G. Lopez-Berestein, J. Intern. Med., 2010, 267(1), 44-53.

13 M. E. Davis, J. E. Zuckerman, C. H. J. Choi, D. Seligson, A. Tolcher, C. A. Alabi, Y. Yen, J. D. Heidel and A. Ribas, Nature, 2010, 464(7291), 1067-1070.

14 A. Fire, S. Xu, M. K. Montgomery, S. A. Kostas, S. E. Driver and C. C. Mello, Nature, 1998, 391(6669), 806-811.

15 K. V. Morris and D. J. Looney, Science, 2004, 305, 1289-1292. 16 V. Winstel, P. Kuhner, B. Krismer, A. Peschel and H. Rohde, Appl. Environ. Microbiol., 2015, 81, 2481-2488.

17 L. Smith, M. Wloch, M. Ye, L. Reyes, S. Boutsaboualoy, C. Dunne, J. Chaplin, D. Rusalov, A. Rolland, C. Fisher, M. Al-Ibrahim, M. Kabongo, R. Steigbigel, R. Belshe, E. Kitt, A. Chu and R. Moss, Vaccine, 2010, 28, 2565-2572. 
18 J. Shen, H. C. Kim, C. Mu, E. Gentile, J. Mai, J. Wolfram, L. N. Ji, M. Ferrari, Z. W. Mao and H. Shen, Adv. Healthcare Mater., 2014, 3, 1629-1637.

19 Z. Yang, T. Liu, Y. Xie, Z. Sun, H. Liu, J. Lin, C. Liu, Z. W. Mao and S. Nie, Acta Biomater., 2015, 25, 194-204.

20 J. H. Choi, H. J. Hwang, S. W. Shin, J. W. Choi, S. H. Um and B. K. Oh, Nanoscale, 2015, 7, 9229-9237.

21 B. K. Wang, X. F. Yu, J. H. Wang, Z. B. Li, P. H. Li, H. Wang, L. Song, P. K. Chu and C. Li, Biomaterials, 2016, 78, 27-39.

22 E. Boisselier and D. Astruc, Chem. Soc. Rev., 2009, 38(6), 1759-1782.

23 M. S. Draz, B. A. Fang, P. Zhang, Z. Hu, S. Gu, K. C. Weng, J. W. Gray and F. F. Chen, Theranostics, 2014, 4(9), 872-892.

24 M. Shilo, T. Reuveni, M. Motiei and R. Popovtzer, Nanomedicine, 2012, 7(2), 257-269.

25 R. K. Sharma, S. Gulati and S. Mehta, J. Chem. Educ., 2012, 89, 1316-1318.

26 R. K. Sharma, S. Sharma, S. Gulati and A. Pandey, Anal. Methods, 2013, 5, 1414-1426.

27 P. Pant, R. Bansal, S. Gulati, S. Kumar and R. Kodwani, Journal of Nanostructures in Chemistry, 2016, 6, 145-157.

28 S. Kumar, Anti-Cancer Agents Med. Chem., 2016, 16, 200-211.

29 B. Madan, S. Batra and B. Ghosh, Mol. Pharmacol., 2000, 58, 526-534.

30 M. Sardana, V. Agarwal, A. Pant, V. Kapoor, K. C. Pandey and S. Kumar, Asian Pac. J. Trop. Biomed., 2018, 8(5), 268272.

31 K. V. Morris and D. J. Looney, Science, 2004, 305, 1289-1292.

32 L. Aagaard and J. J. Rossi, Adv. Drug Delivery Rev., 2007, 59, 75-86.

33 R. Shahbazi, E. Asik, N. Kahraman, M. Turk, B. Ozpolat and K. Ulubayram, Nanomedinice, 2017, 12, 16.

34 R. Shahbazi, B. Ozpolat and K. Ulubayram, Nanomedicine, 2016, 11(10), 1287-1308.

35 Y. Xie, H. Qiao, Z. Su, M. Chen, Q. Ping and M. Sun, Biomaterials, 2014, 35, 7978-7991.

36 Y. Deng, C. C. Wang, K. W. Choy, Q. Du, J. Chen, Q. Wang, L. Li, T. K. Chung and T. Tang, Gene, 2014, 538, 217-227.

37 S. J. Lee, M. J. Kim, I. C. Kwon and T. M. Roberts, Adv. Drug Deliv. Rev., 2016, 104, 2-15.

38 R. Acharya, S. Saha, S. Ray, S. Hazra, M. K. Mitra and J. Chakraborty, Mater. Sci. Eng., C, 2017, 76, 1378-1400.

39 L. Qin, P. Yan, C. Xie, J. Huang, Z. Ren, X. Li, S. Best, X. Cai and G. Hana, Nanoscale, 2018, 10, 13432-13442.

40 P. Resnier, T. Montier, V. Mathieu, J. P. Benoit and C. Passirani, Biomaterials, 2013, 34(27), 6429-6443.

41 G. Meister, M. Landthaler, Y. Dorsett and T. Tuschl, RNA, 2004, 10, 544-550.

42 R. H. Wang, J. Bai, J. Deng, C. J. Fang and X. Chen, ACS Appl. Mater. Interfaces, 2017, 9(7), 5828-5837.

43 Q. Cheng, L. Du, L. Meng, S. Han, T. Wei, X. Wang, Y. Wu, X. Song, J. Zhou, S. Zheng, Y. Huang, X. J. Liang, H. Cao, A. Dong and Z. Liang, ACS Appl. Mater. Interfaces, 2016, 8(7), 4347-4356.

44 Y. Zhao, M. L. Huan, M. Liu, Y. Cheng, Y. Sun, H. Cui, D. Z. Liu, Q. B. Mei and S. Y. Zhou, Sci. Rep., 2016, 6, 35267.
45 Y. Zhao, X. Qi, J. Chen, W. Wei, C. Yu, H. Yan, M. Pu, Y. Li, L. Miao, C. Li and J. Ren, Cancer Lett., 2017, 408, 102-111. 46 J. Kim, C. Jeong and W. J. Kim, Adv. Drug Deliv. Rev., 2016, 98, 99-112.

47 M. Sandbothe, R. Buurman, N. Reich, L. Greiwe, B. Vajen, E. Gurlevik, V. Schaffer, M. Eilers, F. Kuhnel, A. Vaquero, T. Longerich, S. Roessler, P. Schirmacher, M. P. Manns, T. Illig, B. Schlegelberger and B. Skawran, J. Hepatol., 2017, 66(5), 1012-1021.

48 X. Su, H. Wang, W. Ge, M. Yang, J. Hou, T. Chen, N. Li and X. Cao, Cancer Res., 2015, 75(14), 2875-2885.

49 L. Giunti, R. M. Da, S. Vinci, S. Gelmini, A. L. Iorio, A. M. Buccoliero, S. Cardellicchio, F. Castiglione, L. Genitori and M. M. De, Am. J. Cancer Res., 2015, 5(1), 231-242.

50 H. Li, Y. Mu and J. Lu, Anal. Chem., 2014, 86, 3602-3609.

51 C. C. Harris, J. Natl. Cancer Inst., 1996, 88, 1442-1455.

52 D. Naor, Front. Immunol., 2016, 7, 39.

53 D. M. Kokkinakis, A. G. Brickner, J. M. Kirkwood, X. Liu, J. E. Goldwas-ser, A. Kastrama, C. Sander, D. Bocangel and S. Chada, Mol. Cancer Res., 2006, 4, 575-589.

54 S. P. Chaplot and I. D. Rupenthal, J. Pharm. Pharmacol., 2014, 66, 542.

55 Y. Shan, T. Luo, C. Peng, R. Sheng, A. Cao, X. Cao, M. Shen, R. Guo, H. Tomás and X. Shi, Biomaterials, 2012, 33, 30253035.

56 Y. F. Li, H. T. Zhang and L. Xin, J. Cancer Res. Clin. Oncol., 2018, 12, 16.

57 J. Lia, J. Huang, X. Yanga, Y. Yang, K. Quan, N. Xie, Y. Wu, C. Ma and K. Wang, Talanta, 2018, 183, 11-17.

58 Q. Chen, K. Li, S. Wen, H. Liu, C. Peng, H. Cai, M. Shen, G. Zhang and X. Shi, Biomater, 2013, 34, 5200.

59 S. Mansouri, Y. Cuie, F. Winnik, Q. Shi, P. Lavigne, M. Benderdour, E. Beaumont and J. C. Fernandes, Biomater., 2006, 27, 2060.

60 L. S. Mbatha and M. Singh, J. Nanosci. Nanotechnol., 2019, 19, 1959-1970.

61 H. Zhu, W. Liu, Z. Cheng, K. Yao, Y. Yang, B. Xu and G. Su, Int. J. Mol. Sci., 2017, 18, 2029.

62 Y. Lei, L. Tang, Y. Xie, Y. Xianyu, L. Zhang, P. Wang, Y. Hamada, K. Jiang, W. Zheng and X. Jiang, Nat. Commun., 2017, 8, 15130.

63 C. Sardoa, B. Bassib, E. F. Craparoa, C. Scialabbaa, E. Cabrinib, G. Dacarrob, A. D'Agostinob, A. Tagliettib, G. Giammonaa, P. Pallavicinib and G. Cavallaro, Int. J. Pharm., 2017, 519, 113-124.

64 R. Goyal, C. H. Kapadia, J. R. Melamed, R. S. Riley and E. S. Day, Cell. Mol. Bioeng., 2018, 11(5), 383-396.

65 A. Verma and K. Mehta, Curr. Cancer Drug Targets, 2007, 7, 559-565.

66 J. Wang, M. Thomas, P. Lin, J. X. Cheng, D. E. Matei and A. Wei, Bioconjugate Chem., 2019, 30(2), 443-453.

67 S. M. Mantovani and B. S. Moore, J. Am. Chem. Soc., 2013, 135, 18032-18035.

68 V. Nandwana, I. Samuel, G. Cooke and V. M. Rotello, Accounts Chem. Res., 2012, 46, 1000-1009. 
69 A. Sau, S. Sanyal, K. Bera, S. Sen, A. K. Mitra, U. Pal, P. K. Chakraborty, S. Ganguly, B. Satpati, C. Das and S. Basu, ACS Appl. Mater. Interfaces, 2018, 10(5), 4582-4589.

70 C. Bang and T. Thum, Int. J. Biochem. Cell Biol., 2012, 44, 2060-2064.

71 C. Roma-Rodrigues, A. R. Fernandes and P. V. Baptista, BioMed Res. Int., 2014, 2014, 1-10.

72 J. Zhang, S. Li, L. Li, M. Li, C. Guo, J. Yao and S. Mi, J. Proteomics Bioinf., 2015, 13, 17-24.

73 B. N. Hannafon and W. Q. Ding, Int. J. Mol. Sci., 2013, 14, 14240-14269.

74 C. Roma-Rodrigues, F. Pereira, A. P. A. de Matos, M. Fernandes, P. V. Baptista and A. R. Fernandes, Nanomed. Nanotechnol. Biol. Med., 2017, 13(4), 1389-1398.

75 X. Chen, Q. Zhang, J. Li, M. Yang, N. Zhao and F. J. s Xu, ACS Nano, 2018, 12(6), 5646-5656.

76 J. H. Choi, H. J. Hwang, S. W. Shin, J. W. Choi, S. H. Um and B. K. Oh, Nanoscale, 2015, 7, 9229-9237.

77 B. K. Wang, X. F. Yu, J. H. Wang, Z. B. Li, P. H. Li, H. Wang, L. Song, P. K. Chu and C. Li, Biomaterials, 2016, 78, 27-39.

78 H. J. Kim, A. Kim, K. Miyata and K. Kataoka, Adv. Drug Deliv. Rev., 2016, 104, 61-77.

79 K. J. F. Carnevale and G. F. Strouse, Bioconjugate Chem., 2018, 29(10), 3429-3440.

80 Z. Zhang, L. Wang, J. Wang, X. Jiang, X. Li, Z. Hu, Y. Ji, X. Wu and C. Chen, Adv. Mater., 2012, 24, 1418-1423.

81 J. Niua, Y. Chua, Y. F. Huang, Y. S. Chong, Z. H. Jiang, Z. W. Mao, L. H. Penga and J. Q. Gao, ACS Appl. Mater. Interfaces, 2017, 9(11), 9388-9401.

82 J. R. Baker Jr, Hematol Am Soc Hematol Educ Program, 2009, 1, 708-719.

83 J. Deng, N. Li, K. Mai, C. Yang, L. Yan and L. M. Zhang, J. Mater. Chem., 2011, 21, 5273-5281.

84 V. M. Platt and F. C. Szoka, Mol. Pharm., 2008, 5, 474-486. 85 W. Wang, S. Huang, J. Yuan, X. Xu, H. Li, Z. Lv, W. Yu, S. Duan and Y. Hu, Mol. Pharm., 2018, 15(9), 3767-3776.

86 O. Boussif, F. Lezoualc'h, M. A. Zanta, M. D. Mergny, D. Scherman, B. Demeneix and J. P. Behr, Proc. Natl. Acad. Sci. U. S. A., 995, 92, 7297-7301.

87 U. Lungwitz, M. Breunig, T. Blunk and A. Gö pferich, Eur. J. Pharm. Biopharm., 2005, 60, 247-266.

88 A. Li, J. Qiu, B. Zhou, B. Xu, Z. Xiong, X. Hao, X. Shi and X. Cao, Arabian J. Chem., 2018, DOI: 10.1016/ j.arabjc.2018.06.009.

89 D. Wang and R. N. DuBois, Oncogene, 2010, 29, 781.

90 W. K. K. Wu, J. J. Y. Sung, C. W. Lee, J. Yu and C. H. Cho, Cancer Lett., 2010, 295, 7-16.

91 X. Z. Yang, J. Z. Du, S. Dou, C. Q. Mao, H. Y. Long and J. Wang, ACS Nano, 2012, 6, 771.

92 L. Zhang, W. Zheng, R. Tang, N. Wang, W. Zhang and X. Jiang, Biomaterials, 2016, 104, 269.

93 P. Wang, L. Zhang, Y. Xie, N. Wang, R. Tang, W. Zheng and X. Jiang, Adv. Sci., 2017, 4, 1700175.

94 Y. G. Assaraf, C. P. Leamon and J. A. Reddy, Drug Resist. Updates, 2014, 17, 89.

95 J. Akinyelu and M. Singh, J. Nanosci. Nanotechnol., 2018, 18(7), 4478-4486.
96 M. F. Press, G. Sauter, L. Bernstein, I. E. Villalobos, M. Mirlacher, J. Y. Zhou, R. Wardeh, Y. T. Li, R. Guzman, Y. Ma, J. Sullivan-Halley, A. Santiago, J. M. Park, A. Riva and D. J. Slamon, Clin. Cancer Res., 2005, 11, 6598-6607.

97 A. Berchuck, R. Whitaker, G. Olt, J. T. Soper, D. L. ClarkePearson, A. Kamel, R. C. Bast Jr and S. Yin, Cancer Res., 1990, 50, 4087-4091.

98 R. Kotcherlakotaa, D. J. Srinivasanb, S. Mukherjeea, M. M. Haroonb, G. H. Darb, U. Venkatramanb, C. R. Patra and V. Gopal, J. Mater. Chem. B, 2017, 5, 7082-7098.

99 A. A. Bapat, G. Hostetter and D. D. Von Hoff, Nat. Rev. Cancer, 2011, 11, 695-707.

100 G. O. Ceyhan, I. E. Demir, U. Rauch, F. Bergmann, M. W. Müller, M. W. Büchler, H. Friess and K. H. Schäfer, Am. J. Gastroenterol., 2009, 104, 2555-2565.

101 P. D. Zamore, T. Tuschl, P. A. Sharp and D. P. Bartel, Cell, 2000, 101, 25-33.

102 S. M. Hammond, E. Bernstein, D. Beach and G. J. Hannon, Nature, 2000, 404, 293-296.

103 L. A. MacFarlane and P. R. Murphy, Curr. Genom., 2010, 11, 537-561.

104 Z. W. Wu, C. T. Chien, C. Y. Liu, J. Y. Yan and S. Y. Lin, J. Drug Target., 2012, 20, 551-560.

105 K. A. Avery-Kiejda, S. G. Braye, A. Mathe, J. F. Forbes and R. J. Scott, BMC Cancer, 2014, 14, 51.

106 L. Li, L. Yuan, J. Luo, J. Gao, J. Guo and X. Xie, Clin. Exp. Med., 2013, 13, 109-117.

107 D. Ben-Shushan, E. Markovsky, H. Gibori, G. Tiram, A. Scomparin and R. Satchi-Fainaro, Drug Delivery Transl. Res., 2014, 4, 38-49.

108 H. Dong, J. Lei, L. Ding, Y. Wen, H. Ju and X. Zhang, Chem. Rev., 2013, 113(8), 6207-6233.

109 D. Sidransky, Science, 1997, 278(5340), 1054-1058.

110 D. P. Bartel, Cell, 2004, 116(2), 281-297.

111 A. Shenoy and R. H. Blelloch, Nat. Rev. Mol. Cell Biol., 2014, 15(9), 565-576.

112 M. Jin, T. Zhang, C. Liu, M. A. Badeaux, B. Liu, R. Liu, C. Jeter, X. Chen, A. V. Vlassov and D. G. Tang, Cancer Res., 2014, 74(15), 4183-4195.

113 G. A. Calin and C. M. Croce, Nat. Rev. Cancer, 2006, 6(11), 857-866.

114 B. J. Reinhart, F. J. Slack, M. Basson, A. E. Pasquinelli, J. C. Bettinger, A. E. Rougvie, H. R. Horvitz and G. Ruvkun, Nature, 2000, 403(6772), 901-906.

115 B. Li, P. Chen, Y. Chang, J. Qi, H. Fu and H. Guo, Biochem. Biophys. Res. Commun., 2016, 478(2), 739-745.

116 H. Lee, S. Han, C. S. Kwon and D. Lee, Protein Cell, 2016, 7(2), 100-113.

117 D. J. Li, Y. Chen and Z. Liu, Chem. Soc. Rev., 2015, 44(22), 8097-8123.

118 D. Sturm, S. Bender, D. T. W. Jones, P. Lichter, J. Grill, O. Becher, C. Hawkins, J. Majewski, C. Jones, J. F. Costello, A. Iavarone, K. Aldape, C. W. Brennan, N. Jabado and S. M. Pfister, Nat. Rev. Cancer, 2014, 14, 92-107.

119 L. Galluzzi, O. Kepp, M. G. Vander Heiden and G. Kroemer, Nat. Rev. Drug Discov., 2013, 12, 829-846. 
120 J. Yue, T. J. Feliciano, W. Li, A. Lee and T. W. Odom, Bioconjugate Chem., 2017, 28(6), 1791-1800.

121 B. Du, X. Gu, X. Han, G. Ding, Y. Wang, D. Li, E. Wang and J. Wang, ChemMedChem, 2017, 12, 1768-1775.

122 K. Zagorovsky, L. Y. T. Chou and W. C. M. Chan, Proc. Natl. Acad. Sci. U. S. A., 2016, 113, 13600-13605.

123 L. Y. Chou, K. Zagorovsky and W. C. Chan, Nat. Nanotechnol., 2014, 9, 148-155.

124 R. Prado-Gotor and E. Grueso, Phys. Chem., 2011, 3, 14791489.

125 E. Grueso, P. Perez-Tejeda, R. Prado-Gotor and C. Cerrillos, J. Phys. Chem. C, 2014, 4416-4428.

126 E. Grueso, P. Perez-Tejeda, R. M. Giráldez-Pérez, R. PradoGotor and F. Muriel-Delgado, J. Colloid Interface Sci., 2018, 529, 65-76.

127 J. B. Wolinsky, Y. L. Colson and M. W. Grinstaff, J. Controlled Release, 2012, 159, 14-26.

128 M. Ihle, M. Trautmann, H. Kuenstlinger, S. Huss, C. Heydt, J. Fassunke, E. Wardelmann, S. Bauer, H. Schildhaus, R. Buettner and S. Merkelbach-Bruse, Mol. Oncol., 2015, 9, 1421-1433.

129 S. Rietwyk and D. Peer, ACS Nano, 2017, 11, 7572-7586.

130 C. Zhang, Y. Yong, L. Song, X. Dong, X. Zhang, X. Liu, Z. Gu, Y. Zhao and Z. Hu, Adv. Healthcare Mater., 2016, 5, 27762787.

131 S. Kang, K. Kang, H. Huh, H. Kim, S. J. Chang, T. Jung Park, Ki S. Chang, D.-H. Min and H. Jang, ACS Appl. Mater. Interfaces, 2017, 9(40), 35268-35278.
132 Z. Zhou, W. Zheng, J. Kong, Y. Liu, P. Huang, S. Zhou, Z. Chen, J. Shi and X. Chen, Nanoscale, 2017, 9, 6846-6853.

133 W. Fan, N. Lu, C. Xu, Y. Liu, J. Lin, S. Wang, Z. Shen, Z. Yang, J. Qu, T. Wang, S. Chen, P. Huang and X. Chen, ACS Nano, 2017, 11, 5864-5872.

134 J. Shi, M. Sun, X. Sun and H. Zhang, J. Mater. Chem. B, 2016, 4, 7845-7851.

135 R. Yuvakkumar, V. Elango, V. Rajendran and N. Kannan, Digest Journal of Nanomaterials and Biostructures, 2011, 6, 1771.

136 X. Zhao, J. Zhong, C. Wei, C. W. Lin and T. Ding, Front. Microbiol., 2017, 8, 580.

137 X. Zhao, C. W. Lin, J. Wang and D. H. Oh, J. Microbiol. Biotechnol., 2014, 24, 297-312.

138 X. Zhao and C. W. Lin, RSC Adv., 2017, 7, 48554-48560.

139 S. Qian, M. Lin, W. Ji, H. Yuan, Y. Zhang, Z. Jing, J. Zhao, J. F. Masson and W. Peng, ACS Sens, 2018, 3(5), 929-935.

140 L. He, M. D. Musick, S. R. Nicewarner, F. G. Salinas, S. J. Benkovic, M. J. Natan and C. D. Keating, J. Am. Chem. Soc., 2000, 122(38), 9071-9077.

141 S. Szunerits, J. Spadavecchia and R. Boukherroub, Rev. Anal. Chem., 2014, 33, 153.

142 B. Xu, A. Li, X. Hao, R. Guo, X. Shi and X. Cao, RSC Adv., 2018, 8, 1265.

143 Y. Li, H. Wang, K. Wang, Q. Hu, Q. Yao, Y. Shen, G. Yu and G. Tang, Small, 2017, 13, 1602697.

144 C. Ma, L. Shi, Y. Huang, L. Shen, H. Peng, X. Zhu and G. Zhou, Biomater. Sci., 2017, 5, 494-501. 